\title{
Regenerative furnace simulation under flameless combustion regime with natural gas and syngas
}

INGENIERÍA MECÁNICA

\section{Simulación de un horno regenerativo bajo el régimen de combustión sin llama usando gas de síntesis y gas natural}

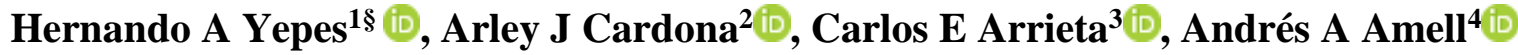 \\ ${ }^{1}$ Universidad Francisco de Paula Santander - Ocaña, Departamento de Ingeniería Mecánica, Grupo de \\ Investigación en Nuevas Tecnologías, Sostenibilidad e Innovación (GINSTI), Ocaña, Colombia \\ ${ }^{2}$ Instituto Tecnológico Metropolitano, Facultad de Ingenierías, Grupo de Investigación de Materiales \\ Avanzados y Energía (MATyER), Medellín, Colombia. \\ ${ }^{3}$ Universidad de Medellín, Facultad de Ingenierías, Grupo de investigación en Energía, Medellín, \\ Colombia. \\ ${ }^{4}$ Universidad de Antioquia, Facultad de Ingeniería, Grupo de Ciencia y Tecnología del Gas y Uso \\ Racional de la Energía (GASURE), Medellín, Colombia \\ \$ hayepest@ufpso.edu.co,arleycardona5670@correo.itm.edu.co,carrieta@udem.edu.co,andres.amell@udea.edu.co
}

Recibido: 17 de febrero de 2021 - Aceptado: 11 de junio de 2021

\begin{abstract}
The increase in pollutant emissions has generated the development of clean technologies and encouraged the use of alternative fuels like syngas. Flameless combustion is one of the most promising clean technologies due to lower pollutants emissions and high thermal efficiency. In the present study, regenerative furnace simulation under flameless combustion was carried out using a fuel mixture of $70 \%$ natural gas and 30\% syngas with high $\mathrm{H}_{2}$ content (in vol.); by mean of CFD approach. A symmetrical mesh with 405,632 hexahedral cells was used in the calculations. The $\kappa-\varepsilon$ standard, discrete ordinates and Eddy Dissipation Concept models were used for physical phenomena of turbulence,


radiation and turbulence - chemistry interaction, respectively. The combustion chambers thermal uniformity factor was 0.3 and 0.1 for vertical and horizontal planes, respectively. The results confirm that it is possible to achieve the flameless combustion regime in a regenerative furnace using the addition of syngas, preserving the temperature and reaction zone uniformity.

Keywords: CFD, flameless, natural gas, regenerative furnace, syngas.

\section{Resumen}

El aumento en las emisiones contaminantes ha generado el desarrollo de tecnologías limpias y alentado el uso de combustibles alternativos como el gas de síntesis. La combustión sin llama es una de las tecnologías limpias más promisorias debido al bajo nivel de emisiones y las altas eficiencias térmicas que permite obtener. En el presente estudio, se llevó a cabo la simulación de un horno regenerativo bajo condiciones de combustión sin llama, utilizando una mezcla combustible de $70 \%$ gas natural y $30 \%$ gas de síntesis con alto contenido de $\mathrm{H}_{2}$ (en vol.), por medio del enfoque de dinámica de fluidos computacional. Para los cálculos se construyó un mallado simétrico de 405,632 celdas hexaédricas. Los modelos $\kappa-\varepsilon$ estándar, ordenadas discretas y Eddy Dissipation Concept fueron implementados para la turbulencia, radiación y la interacción química - turbulencia, respectivamente. El índice de uniformidad térmica de la cámara de combustión fue de 0.3 y 0.1 para los planos vertical y horizontal respectivamente. Los resultados confirman que es posible obtener el régimen de combustión sin llama en un horno regenerativo usando la adición de gas de síntesis, conservando la uniformidad en la temperatura y la zona de reacción.

Palabras clave: CFD, combustión sin llama, gas natural, gas de síntesis, horno regenerativo.

\section{Introduction}

The growth of world energy demand along with increases in pollutant emissions ${ }^{(1)}$ has generated the development of clean and efficient technologies, besides the alternative fuels use like syngas due to their high $\mathrm{H}_{2}$ content ${ }^{(2)}$. Inside from these technologies, it is the flameless combustion, in which the principal characteristics are the absence of visible flame front, uniform temperature and species profiles along with low emissions ${ }^{(3)}$. On the other hand, natural gas is less polluting within fossil fuels because their use does not generate sulfides and have low soot emissions. For these reasons, the only fossil fuel that appears with a higher consumption rate in the year 2035 compared to that present ${ }^{(4)}$.

Under these circumstances, the use of both fuels and the blends among them, along with flameless combustion technology, can be a promising strategy to reduce the thermal energy consumption. There are many studies focused on the use of fossil fuels at flameless combustion regime ${ }^{(5-13)}$ as well as in mixtures of them with $\mathrm{H}_{2}{ }^{(14-18)}$ but is more limited the reported studies with use mixtures between natural gas and syngas and much scarcer if industrial or semi-industrial furnaces are considered as experimental devices.

Shabanian et al. ${ }^{(19)}$ studied numerically the NOx emissions, the thermal and species profiles using syngas as fuel in laboratory-scale atmospheric burner. They found that the numerical predictions reproduced the experimental results with good agreement when the eddy dissipation concept model was used with the Reynolds stress model. On the other hand, Huang et al. ${ }^{(20,21)}$ conducted some studies using syngas with high hydrogen content $\left(38 \% \mathrm{H}_{2}\right.$ molar basis). According to the results, the high velocity in the reactants discharge enhances the mixing and contributes to obtain the regime. For the emissions, according to the sensibility analysis carried out by the authors, the principal pathway to produce NOx using syngas under the flameless combustion regime is through the $\mathrm{N}_{2} \mathrm{O}$ intermediate route. More recently, the same authors evaluated four typical syngas fuels 
using the same experimental setup of previous studies, operating the combustor in a 12.2 to 27.5 $\mathrm{kW}$ thermal input.

Their kinetic analysis exposes that the amount of $\mathrm{CO}$ and $\mathrm{H} 2$ change the trigger ignition reactions. For $\mathrm{H} 2$-enriched syngas, the ignition is dominated by $\mathrm{H}$ and $\mathrm{HO} 2$ radical reactions. Meanwhile, for $\mathrm{CO}$-enriched syngas, the $\mathrm{CO}+\mathrm{OH}=\mathrm{H}+\mathrm{CO} 2$ is the most relevant at the ignition process ${ }^{(22)}$. Mardani et al. (23) evaluated the $\mathrm{CH} 4$ enrichment with syngas in a hot coflow burner. The syngas mixtures show higher stability when $\mathrm{O} 2$ is variated in the oxidizer in comparison to $\mathrm{CH} 4$. However, in the study CH4-Syngas blends were not evaluated. Various studies focused on the NOx formation pathways have been carried out recently using syngas at flameless conditions, but all of them were performed in coflow and counterflow burners ${ }^{(24-26)}$.

The mentioned studies with syngas were developed using burners that help to emulate the conditions to achieve a flameless combustion regime, such as axially staged combustor, external dilution and jet hot coflow burners, limiting the real interaction between the jets and recirculation process. Besides, the $\mathrm{CH} 4-\mathrm{Syngas}$ mixtures were not evaluated.

Due to these reasons, it is necessary to study the use of natural gas and syngas mixtures at the flameless combustion regime to extend the use of alternative fuels like syngas and contribute to energy requirements under an environmentfriendly approach. In the present study, the computational fluid dynamics (CFD) was used to evaluate a semi-industrial regenerative furnace performance, which was initially designed for natural gas (NG), using a mixture of $70 \% \mathrm{NG}$ and $30 \%$ syngas (In vol.) at steady-state conditions. The following sections expose the numerical methodology and the description of the complementary models used. Subsequently, the results about the thermal field and oxidation process are discussed.

\section{Methodology}

A semi-industrial furnace with a regenerative burner was modeled using Ansys-Fluent 15.0; the furnace was initially designed to operate with natural gas. The schematic inlets and outlets flow are shown in the Figure 1, the details of them can be found in ref ${ }^{(27)}$. The combustion chamber length is $1.35 \mathrm{~m}$. The natural gas composition was approximated to $100 \% \mathrm{CH}_{4}$ since that, in general, is the principal element of this fuel, whichever the source ${ }^{(28-30)}$. For syngas, the chemical composition was established in $40 \% \mathrm{CO}, 40 \% \mathrm{H}_{2}$ and $20 \% \mathrm{CO}_{2}$ (in Vol.), which is typical from gasification biomass or carbon gas ${ }^{(31,32)}$. All performed simulations were carried out at stable state conditions.

\subsection{Computational domain}

The combustion chamber of the furnace was selected as a computational domain. Due to the furnace symmetry, only one half was simulated. A boundary condition of symmetry was used at the middle plane of the combustion chamber (See Figure 2); the mesh used has 405,632 hexahedral cells. The thermal input to the furnace was $20 \mathrm{~kW}$, the excess air ratio was 1.2 and preheated air was simulated by mean of the temperature $(837.15 \mathrm{~K})$ boundary condition for inlet air. The furnace has inner tubes to emulate the thermal load; therefore, a mass flow rate of $0.034 \mathrm{~kg} / \mathrm{s}$ was used. The selected operative conditions correspond to the nominal values used at the furnace operation with natural gas ${ }^{(27,30)}$. For the heat losses with the surroundings, a constant convection heat transfer coefficient of $10 \mathrm{~W} / \mathrm{m}^{2}-\mathrm{k}$ was established according to the references ${ }^{33,34)}$. For all inlets at the furnace, mass flow inlet conditions were used and for outlets, pressure outlet conditions (atmospheric pressure) were established. 


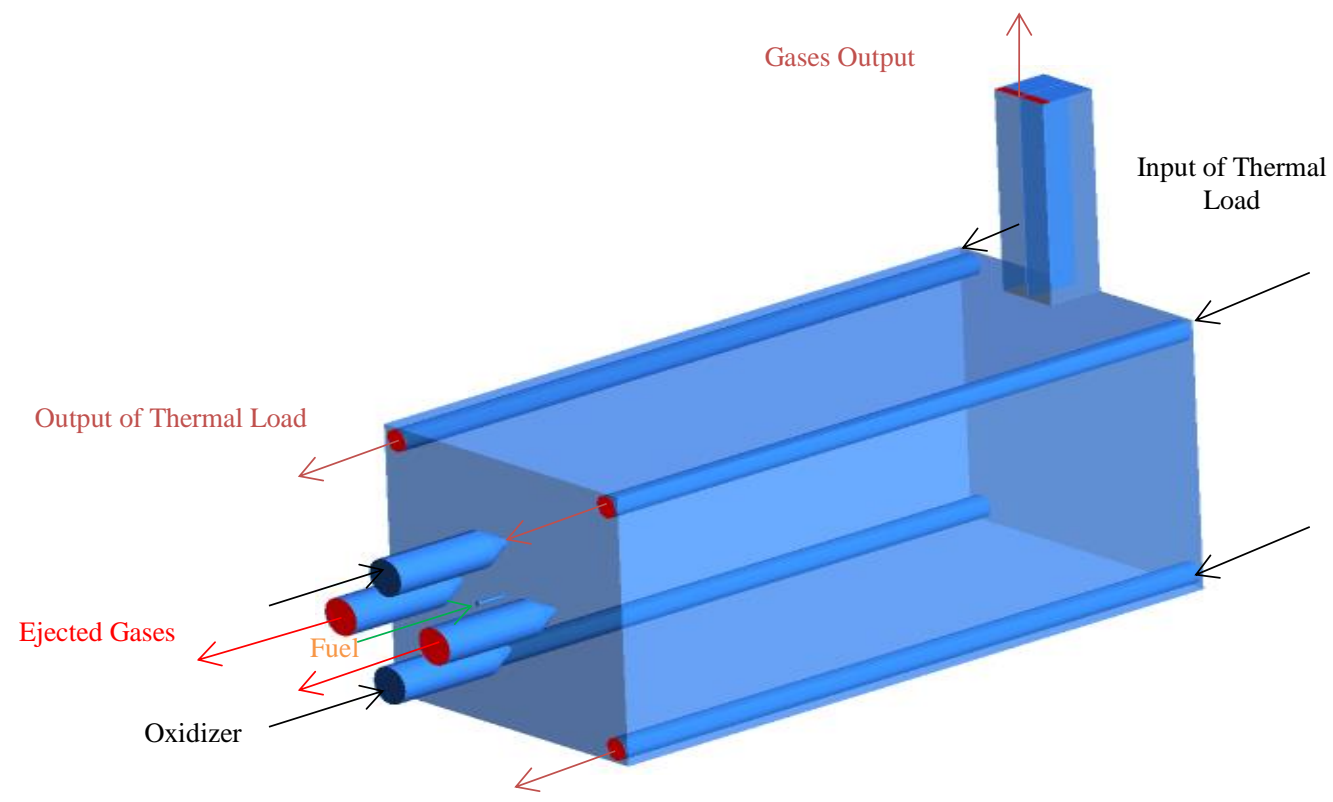

Figure 1. Furnace combustion chamber scheme. Source own elaboration:

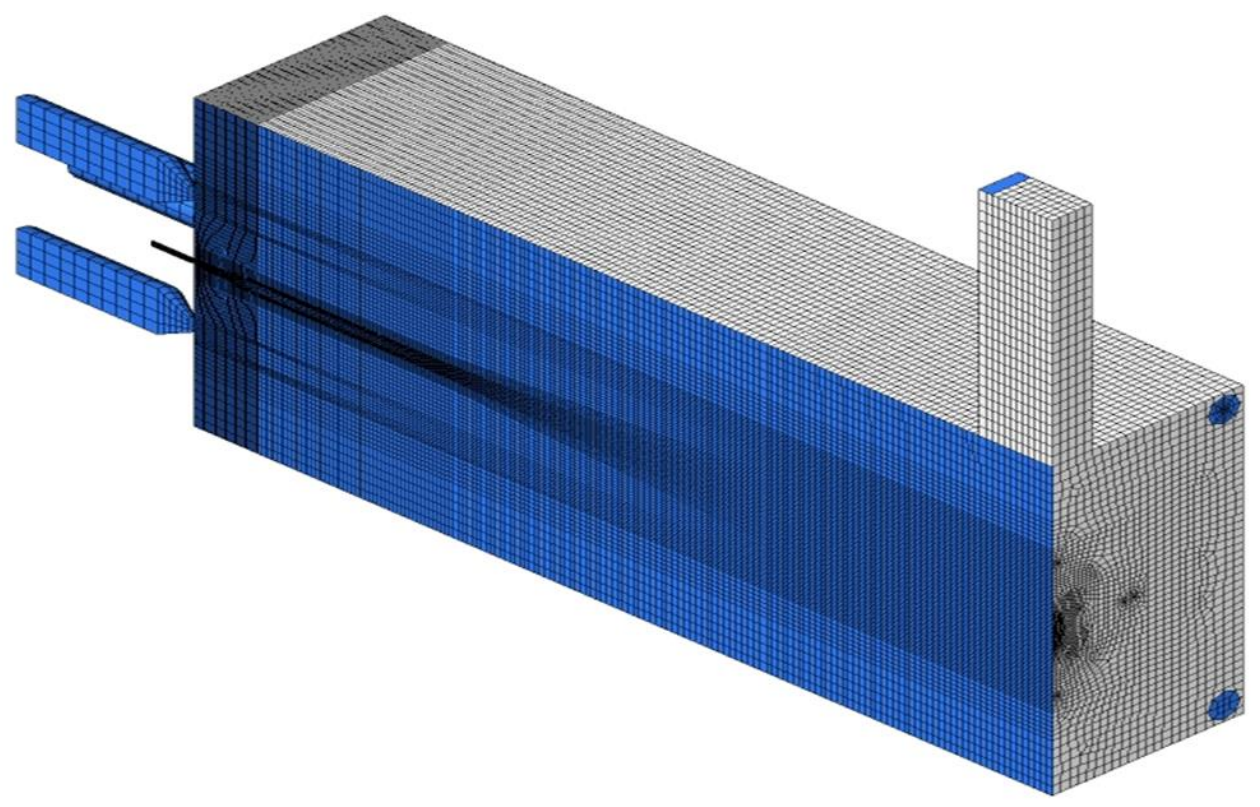

Figure 2. Combustion chamber mesh. Source own elaboration:

\subsection{Fluid dynamics and kinetic models}

The selected models for turbulence, radiation and interaction between chemistry and turbulence are listed in Table 1. These were selected according to the reported in the literature ${ }^{(35,36)}$. In particular, the Eddy Dissipation Concept (EDC) was selected due to the models associated with fast chemistry are not suitable for flameless combustion regime, where the reaction zone is widespread, and the reactions are slower than in conventional combustion. 
Table 1. Complementary models for the simulation

\begin{tabular}{cc}
\hline Phenomena & Model \\
\hline Turbulence & $\mathrm{k}-\varepsilon$ standard \\
Radiation & Discrete ordinates \\
Chemistry - & Eddy Dissipation \\
Turbulence & Concept \\
interaction & \\
Source: Adapted from $^{(37)}$ &
\end{tabular}

The EDC model considerate that the reaction takes place in a finite turbulent structure with scale $\xi^{*}$ in a reaction time $\tau^{*}$ defined according to the Equations ¡Error! No se encuentra el origen de la referencia.) and ¿Error! No se encuentra el origen de la referencia.), respectively.

$$
\begin{aligned}
\xi^{*} & =C_{\xi}\left(\frac{v \varepsilon}{\kappa^{2}}\right)^{1 / 4} \\
\tau^{*} & =C_{\tau}\left(\frac{v}{\varepsilon}\right)^{1 / 2}
\end{aligned}
$$

The $\xi^{*}$ and $\tau^{*}$ are used to calculate the source term in the species transport equation $\left(R_{i}\right)$ according to the Equation (3):

$$
R_{i}=\frac{\rho\left(\xi^{*}\right)^{2}}{\tau^{*}\left[1-\left(\xi^{*}\right)^{3}\right]}\left(Y_{i}^{*}-Y_{i}\right)
$$

Where $\rho$ is the density, $Y_{i}$ the mass fraction of the specie $i$ and $Y_{i}^{*}$ is the mass fraction after reaction time $\tau^{*}$ calculated by Arrhenius reaction model according to the kinetic mechanism. The reaction mechanism used is a modification of the original proposed by Westbrook and Dryer. The global mechanism has composed of five-step reactions and was adjusted to reproduce appropriately the reaction rates at flameless combustion conditions (38). The reactions are shown in Table 2.

\subsection{Numerical solution and convergence criteria}

To solve the transport equations, a first-order discretization scheme was used in the preliminary solution; later, the results were used as an initial guess for the final solution where a second-order scheme was used. An independence mesh test was performed using two additional finest mesh (840,521 and 1,191,921 cells), evaluating the combustion chamber centerline temperature and velocity profiles. Additionally, the grid convergence index (GCI) proposed by Roache ${ }^{(39)}$ was calculated to evaluate the discretization error and estimate the deviation of final calculation respect to asymptotic solution. To calculate the GCI is necessary to determine the estimated precision order, which is calculated according to Equations ¡Error! No se encuentra el origen de la referencia.), ¡Error! No se encuentra el origen de la referencia.) and ¿Error! No se encuentra el origen de la referencia.).

$$
\begin{gathered}
p=\frac{|\ln | \varepsilon_{32} / \varepsilon_{21}|+q|}{\ln \left(r_{21}\right)} \\
q=\ln \left(\frac{r_{21}^{p}-s}{r_{32}^{p}-s}\right) \\
s=\operatorname{sgn}\left(\varepsilon_{32} / \varepsilon_{21}\right)
\end{gathered}
$$

Where $p$ is the estimated precision order, $\varepsilon_{i j}$ is the difference of a specific variable, $r$ is the refinement ratio $r_{i+1, i}=\left(\mathrm{N}_{\mathrm{i}} / \mathrm{N}_{\mathrm{i}+1}\right)^{1 / 3}, N$ is the number of cells in each mesh and the sub-index $i$ refers to the refinement level of them, where $i=1$ is the most refined mesh. Finally, the GCI was estimated for the coarse mesh using Equation ¿Error! No se encuentra el origen de la referencia.) with a security factor $\left(\mathrm{F}_{\mathrm{s}}\right)$ of $1.25^{(40)}$.

$$
G C I_{\text {coarse }}=\frac{F_{S}}{r_{32}^{p}}\left|\frac{\varphi_{2}-\varphi_{3}}{\varphi_{2}}\right|
$$

Where $\varphi i$ is the value of the analysis variable (velocity and temperature in the present study). The GCI was calculated at three different positions in the central axis of the combustion chamber. The solution convergence was established for all calculations when the residual achieved values of $10^{-5}$ for continuity and $10^{-6}$ for energy, velocity, and radiation. Besides, a variation threshold by iteration of 1 degree and 
$0.1 \mathrm{~m} / \mathrm{s}$ was fixed for temperature and velocity, respectively ${ }^{(41)}$. In

Table 3, the GCI values for coarse mesh are exposed. The maximum value is $1.3 \%$, which

Table 2. Global reaction mechanism for flameless combustion (units in kmol, $K, \mathrm{~s}, \mathrm{~kJ}$ and $\mathrm{m}^{3}$ )

\begin{tabular}{|c|c|c|c|c|}
\hline Reaction & Rate orders & $\overline{\mathbf{A}}$ & $\boldsymbol{\beta}$ & $\mathbf{E a} / \mathbf{R}$ \\
\hline $\mathrm{CH}_{4}+1.5 \mathrm{O}_{2} \rightarrow \mathrm{CO}+2 \mathrm{H}_{2} \mathrm{O}$ & {$\left[\mathrm{CH}_{4}\right]^{0.7}\left[\mathrm{O}_{2}\right]^{0.8}$} & $5.03 \times 10^{11}$ & 0 & 24,056 \\
\hline $\mathrm{CO}+0.5 \mathrm{O}_{2} \rightarrow \mathrm{CO}_{2}$ & {$[\mathrm{CO}]\left[\mathrm{H}_{2} \mathrm{O}\right]^{0.5}\left[\mathrm{O}_{2}\right]^{0.25}$} & $2.24 \times 10^{8}$ & 0 & 5,032 \\
\hline $\mathrm{CO}_{2} \rightarrow \mathrm{CO}+0.5 \mathrm{O}_{2}$ & {$\left[\mathrm{CO}_{2}\right]\left[\mathrm{H}_{2} \mathrm{O}\right]^{0.5}\left[\mathrm{O}_{2}\right]^{-0.25}$} & $1.10 \times 10^{13}$ & $\begin{array}{c}- \\
0.97\end{array}$ & 39,452 \\
\hline $\mathrm{H}_{2}+0.5 \mathrm{O}_{2} \rightarrow \mathrm{H}_{2} \mathrm{O}$ & {$\left[\mathrm{H}_{2}\right]\left[\mathrm{O}_{2}\right]^{0.5}$} & $7.91 \times 10^{10}$ & 0 & 17,609 \\
\hline
\end{tabular}

Figure 3 shows the temperature profiles in the central line of the furnace for the three meshes. As can be seen, there does not exist a significant difference between the finest and coarse mesh. Furthermore, the three results expose a flat profile without temperature peaks, which is according to flameless combustion characteristics ${ }^{(27)}$.

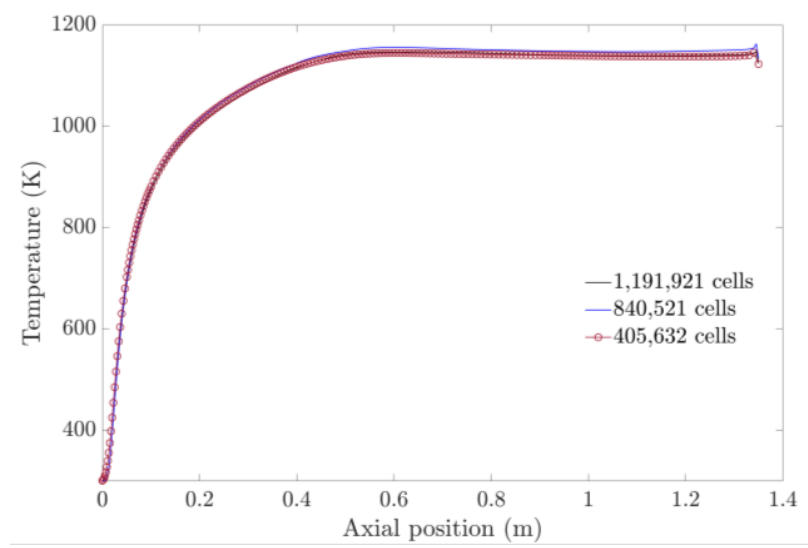

Figure 3. Temperature profiles for the combustion chamber central line. Source own elaboration:

Table 3. GCI for velocity.

\begin{tabular}{cc}
\hline $\begin{array}{c}\text { Axial position } \\
\text { center line }(\mathbf{m})\end{array}$ & GCI $_{\text {coarse }}(\boldsymbol{\%})$ \\
\hline 0.3340 & 0.43 \\
0.6403 & 0.16 \\
1.0042 & 1.3 \\
\hline
\end{tabular}

indicates that the discretization error is low. Therefore, the final calculation results with the coarse grid are suitable from a numerical point of view. 
gas-syngas, the thermal uniformity factor $\left(\mathrm{R}_{\mathrm{tu}}\right)$ was calculated according to defined by Yang et al. (42) for the final three-quarter of the combustion chamber; is in this zone where it is expected that the mixed between fuel and oxidizer take place and therefore the principal reactions occur. Values of $R_{t u}$ close to zero are associated with uniform thermal fields. The $\mathrm{R}_{\mathrm{tu}}$ was calculated in the vertical and horizontal plane, taking the line values located at $0.15 \mathrm{~m}$ of the center lines in both cases. The $\mathrm{R}_{\text {tu }}$ values were 0.3 and 0.1 , respectively, which suggest a high uniformity level, according to the exposed by Rafidi and Blasiak ${ }^{(42)}$. On the other hand, to confirm this trend, the temperature contours are shown in Figure 5, confirming the absence of high gradients inside the combustion chamber.

A third approach to confirm the thermal uniformity was applied. Fluent area-weighted uniformity index was evaluated over vertical and horizontal central planes, besides combustion chamber walls. For this parameter, the uniformity corresponds to values close to unity. The obtained results were $0.98,0.99$ and 0.99 , respectively. According to these values, the furnace thermal uniformity is high, confirming that the temperature field obtained in the simulation agrees with flameless combustion characteristics. Indeed, the maximum temperature achieved inside the combustion chamber was $1,161 \mathrm{~K}$, which is more than $300 \mathrm{~K}$ below of the maximum values at conventional combustion conditions, around $1,475 \mathrm{~K}^{(27)}$, in the same furnace.

The uniformity of the temperature field is a good indicator of flameless combustion. However, this is not the only indicator to ensure the combustion flameless regime achievement. For this reason, the oxidation mixture ratio $\left(R_{0}\right){ }^{(43)}$ was used to estimate the shape of the reaction zone and ascertain if this corresponds to flameless combustion. A value of 1 for $R_{o}$ indicates that no is fuel present at this point, primarily when it is air or when combustion is completed and achieves a value of 0 at the fuel inlet. $R_{o}$ is defined by Equation ;Error! No se encuentra el origen de la referencia.), where $m_{0}$ is the mass fraction of oxygen; $\mathrm{s}=\mathrm{n}_{\mathrm{o}} \mathrm{M}_{\mathrm{o}} / \mathrm{n}_{\mathrm{f}} \mathrm{M}_{\mathrm{f}} ; \mathrm{n}$ is the stoichiometric coefficient and $\mathrm{M}$ is the molecular weight.

$$
R_{o}=\frac{m_{o}}{m_{o}+\sum_{c} s_{c} m_{F, c}}
$$

Figure 6 shows three $R_{0}$ iso-surfaces inside the combustion chamber, corresponding to values of 0.8, 0.9 and 0.99. As can be seen, the surface for $R_{0}=0.8$ has the same length as the combustion chamber, which indicates that the reaction zone is very long. Furthermore, it is evident that the surface of $R_{0}=0.9$ is not near the corresponding to 0.8 , which means that the region where the fuel oxidation continues is broad. Indeed, the results suggest that the reactive mixture achieves the wall combustion chamber in some locations before obtaining higher $\mathrm{R}_{\mathrm{o}}$ values.

According to this is possible to establish that the combustion with the natural gas-syngas fuel mixture takes place at the volumetric zone as is the flameless regime characteristic. Using the value of $R_{0}=0.99$, the volume of the reaction zone was estimated, and this value was used to calculate the furnace flame occupation coefficient (RFOC), which for this case, is $97 \%$. It means that the reaction zone spans almost all the combustion chamber. This behavior can suggest that incomplete combustion can be expected due to the amplitude of a volumetric reaction. However, the $\mathrm{CO}$ emissions at the smokestack are lower than $15 \mathrm{ppm}$, confirming the complete combustion $(10,17)$.

In order to confirm that the regime was achieved with the syngas addition, the temperature and $R_{o}$ were compared to the obtained in the simulation of pure $\mathrm{CH}_{4}$. The flameless combustion regime obtention with this last was validated experimentally in previous work ${ }^{(27)}$. Figure 8 shows the temperature inside the combustion chamber at the centerline for both cases. It is evident that do not exist relevant differences among them. When syngas is present in the fuel, the temperature is slightly higher at the beginning 
of the combustion chamber; this can be associated with the high reactivity of $\mathrm{H}_{2}$, which allows a faster reaction and, therefore greater amount of released energy in this zone. However, in the second half of the combustion chamber, the temperature is almost equal with relative differences lower than $1.6 \%$ with respect to the natural gas case; this behavior is due to flue gas recirculation. Indeed, the fluid dynamics pattern are very similar, according to the streamlines (See Figure 7).

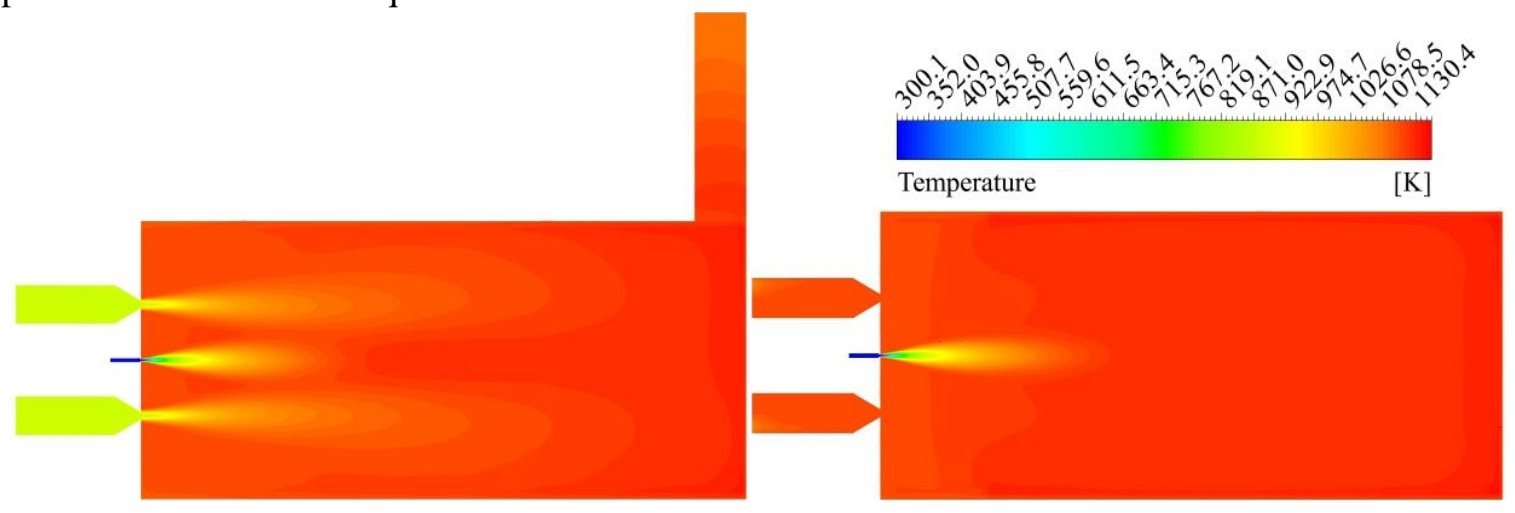

Figure 5. Temperature contours. Vertical plane (left). Horizontal plane (right). Source: own elaboration

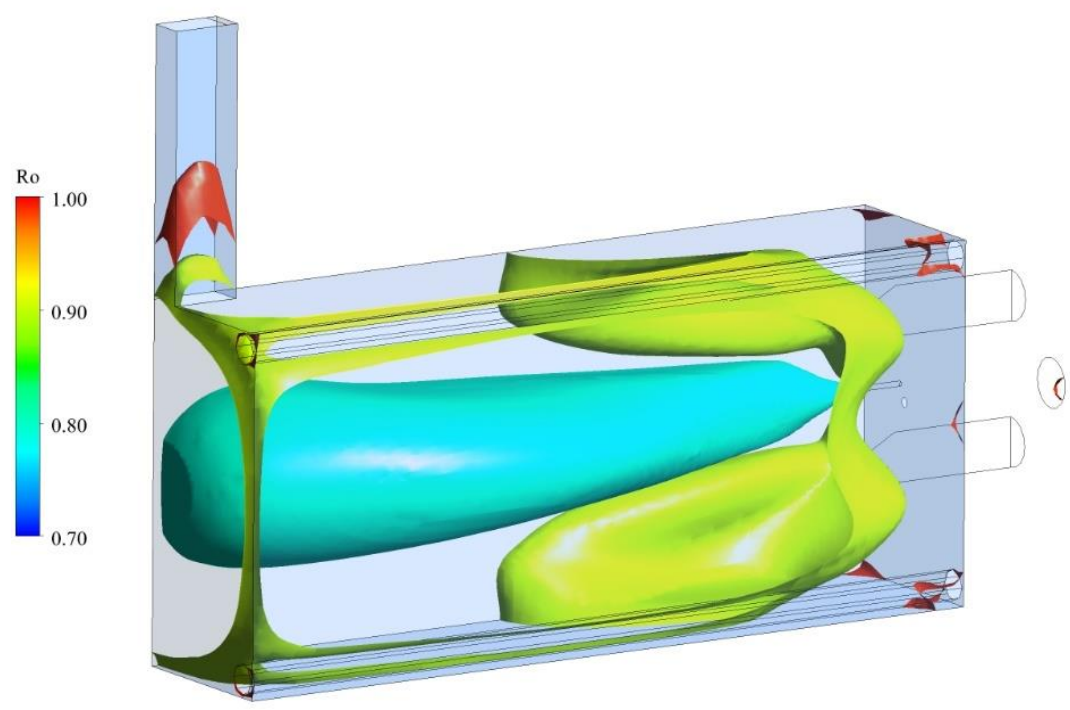

Figure 6. $R_{o}$ Iso-surfaces for values of 0.8, 0.9 and 0.99. Source: own elaboration 

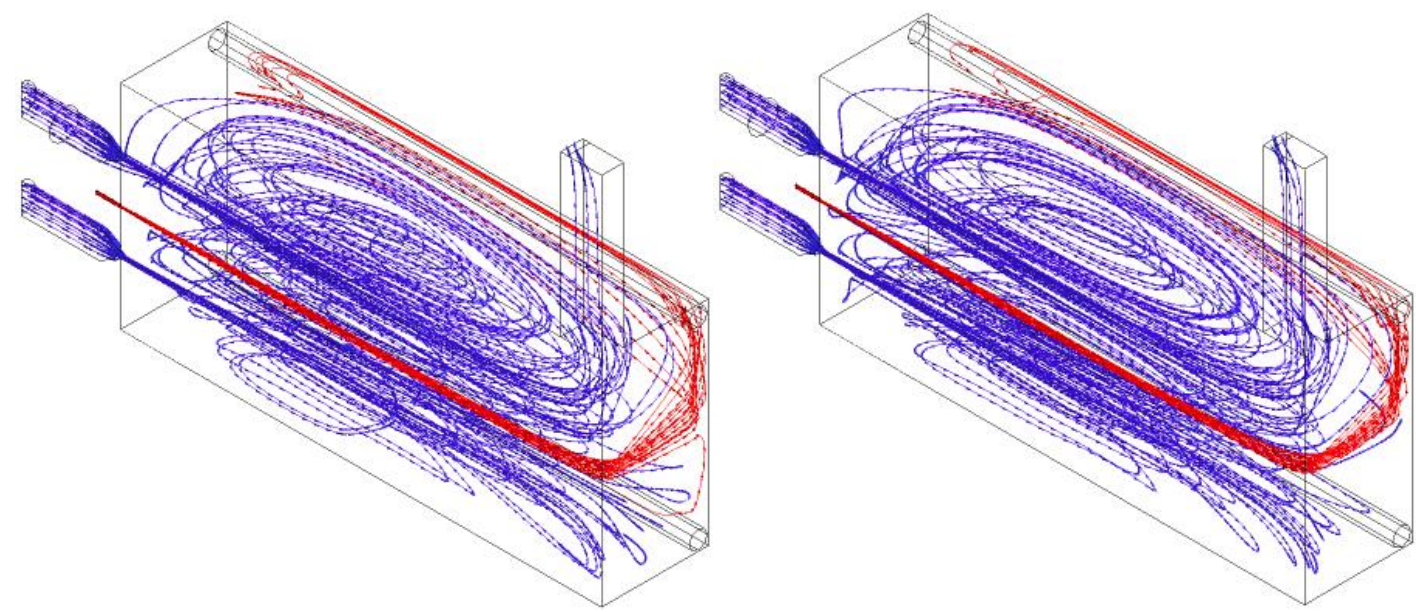

Figure 7. Streamlines for fuel (red) and air (blue). $70 \% \mathrm{CH}_{4}-30 \%$ Syngas (left). $100 \% \mathrm{CH}_{4}(\mathrm{Right})$. Source: own elaboration

The closeness between temperature profiles confirms that the results with syngas addition are according to the flameless combustion regime, as it shows Figure 8. Finally, in Figure 9, the Ro in the centerline is shown. The behavior is consistent with the temperature profile. The oxidation is higher until an axial distance of $0.5 \mathrm{~m}$ approximately of the combustion chamber when the syngas is present in the fuel and achieve the same values as the $\mathrm{CH}_{4}$ case from higher values.

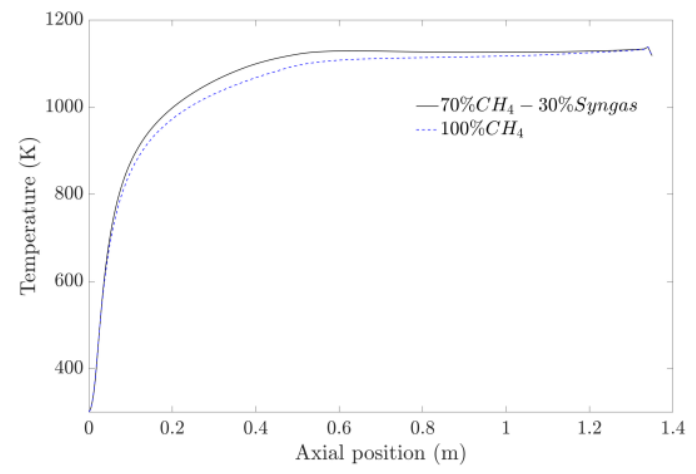

Figure 8. Temperature profiles at the central line for the mixture and pure $\mathrm{CH}_{4}$. Source: own elaboration

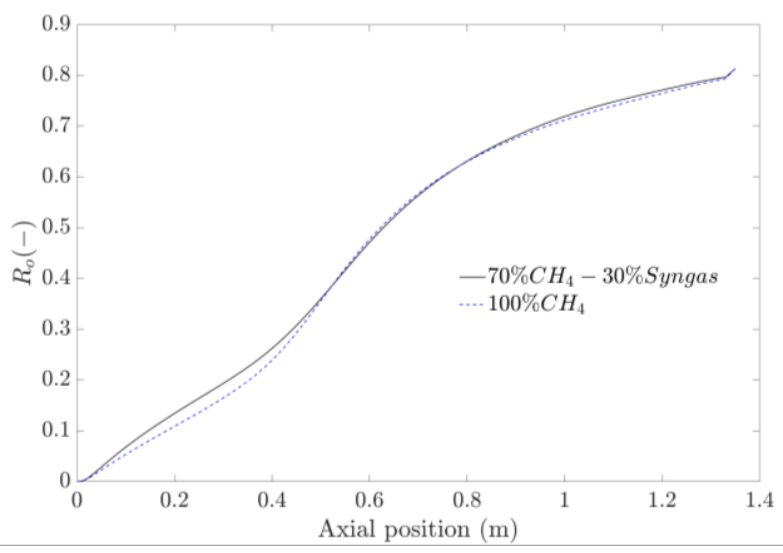

Figure 9. $R_{o}$ profiles at the central line for the mixture and pure $\mathrm{CH}_{4}$. Source: own elaboration

The results suggest that the recirculation generated by jet discharge is enough to obtain the regime but lower to generates unsteady and incomplete combustion. The combined uniformity temperature fields and the broad reaction zone allows establishing that the flameless combustion regime can be achieved using the addition of $30 \%$ in volume of syngas to natural gas, even if the furnace was designed to operate only with natural gas. Moreover, the RFOC obtained from the simulation for both cases is the same.

The simulation results are promising in order of the flexibility of flameless combustion and the future implementation of this technology to 
operate with alternative and fossil fuels blends. The next step from this research is the experimental evaluation to confirm the obtained results. Additionally, higher additions of syngas mixture with different compositions must be evaluated.

\section{Conclusions}

A numerical study of the combustion chamber from regenerative furnace operating at a flameless combustion regime using a mixture of $70 \%$ natural gas and $30 \%$ syngas in volume was performed. The discretization error and independence grid were evaluated and then the attainment of flameless combustion was tested. The uniform temperature profiles and the broad reaction zone obtained of numerical results suggest that the flameless combustion regime can be achieved with the mixture operating at thermal input of $20 \mathrm{~kW}$ without any geometrical modification and in stable conditions.

The temperature, $\mathrm{R}_{\mathrm{o}}$ and RFOC obtained numerically when the syngas was added to the fuel were compared with the case of $100 \%$ natural gas $\left(\mathrm{CH}_{4}\right)$, which was previously validated experimentally in previous work. The temperature and $R_{o}$ profiles are very similar; only slightly higher values are present at the beginning of the combustion chamber due to the high reactivity of $\mathrm{H}_{2}$ present in the syngas. They confirm that it is possible to obtain the flameless combustion regime when syngas is added without significant thermal and kinetic profiles disturbance.

\section{Acknowledgment and Funding Statement}

The authors gratefully acknowledge to the sustainability program of the Vice-rectory for Research 2020-2021 of the Universidad de Antioquia - UdeA for the valuable economic contribution toward the development of this research.

\section{References}

(1) Energy Information Administration, Administration USEI. International Energy Outlook 2019 with projections to 2050. Washington, DC.

(2) Burbano HJ, Pareja J, Amell AA. Laminar burning velocities and flame stability analysis of syngas mixtures at sub-atmospheric pressures. Int J Hydrogen Energy 2011; 36: $3243-$ 3252. Epub ahead of print 2011. https://doi.org/10.1016/j.ijhydene.2010.12.001.

(3) Cavaliere A, de Joannon M. Mild Combustion. Prog Energy Combust Sci 2004; 30: 329-366. Epub ahead of print January 2004. https://doi.org/10.1016/j.pecs.2004.02.003.

(4) International Energy Agency. World Energy Outlook 2016. U.S. Department of Energy.

(5) Seliger $\mathrm{H}$, Huber A, Aigner $\mathrm{M}$. Experimental Investigation of a FLOX®-Based Combustor for a Small-Scale Gas Turbine Based CHP System Under Atmospheric Conditions. ASME Turbo Expo 2015 2015; 1-13. Epub ahead of print 2015. https://doi.org/10.1115/GT201543094.

(6) Shabanian SR, Medwell PR, Rahimi M, et al. Kinetic and fluid dynamic modeling of ethylene jet flames in diluted and heated oxidant stream combustion conditions. Appl Therm Eng 2013; 52: 538-554. Epub ahead of print 2013. https://doi.org/10.1016/j.applthermaleng.2012.12 .024

(7) Lezcano C, Obando J, Amell A. Numerical simulation of a flameless combustion furnace with mixtures of methane and a subbituminous pulverized Coal. Combust Sci 
Technol 2017; 189: 1591-1604. Epub ahead of print

2017.

https://doi.org/10.1080/00102202.2017.1305370

(8) Doan NAK, Swaminathan N. Autoignition and flame propagation in nonpremixed MILD combustion. Combust Flame 2019; 201: 234-243. Epub ahead of print 1 March 2019.

https://doi.org/10.1016/J.COMBUSTFLAME.20 18.12 .025

(9) Cheong KP, Wang G, Wang B, et al. Stability and emission characteristics of nonpremixed MILD combustion from a paralleljet burner in a cylindrical furnace. Energy 2019; 170: 1181-1190. Epub ahead of print 1 March 2019.

https://doi.org/10.1016/j.energy.2018.12.146

(10) Mao Z, Zhang L, Zhu X, et al. Experiment investigation of coal MILD-Oxy combustion integrated with flue gas recirculation at a 0.3 MWth furnace. Fuel Process Technol 2017; 162: 126-134. Epub ahead of print 1 July 2017.

https://doi.org/10.1016/j.fuproc.2017.04.002

(11) $\mathrm{Hu} F$, Li P, Guo J, et al. Optimal Equivalence Ratio to Minimize NO Emission during Moderate or Intense Low-Oxygen Dilution Combustion. Energy and Fuels 2018; 32: 4478-4492. Epub ahead of print 1 February 2018. https://doi.org/10.1021/acs.energyfuels.7b03162.

(12) Xie M, Dai F, Tu Y. A numerical study of accelerated moderate or intense low-oxygen dilution (MILD) combustion stability for methane in a lab-scale furnace by off-stoichiometric combustion technology. Chinese J Chem Eng 2021; 32: 108-118. Epub ahead of print 1 April 2021.

https://doi.org/10.1016/j.cjche.2020.09.053

(13) Aanjaneya K, Chen Y, Cao W, et al. A numerical study of localized swirling injection of oxidizer for homogeneous combustion with oxygen enrichment. Fuel 2021; 283: 118773. Epub ahead of print 1 January 2021. https://doi.org/10.1016/j.fuel.2020.118773

(14) Wang F, Mi J, Li P, et al. Diffusion flame of a $\mathrm{CH} 4$ / $\mathrm{H} 2$ jet in hot low-oxygen coflow. Int J Hydrogen Energy 2011; 6: 9267-9277. Epub ahead of print 2011. https://doi.org/10.1016/j.ijhydene.2011.04.180

(15) Ayoub M, Rottier C, Carpentier S, et al. An experimental study of mild flameless combustion of methane/hydrogen mixtures. Int $\mathbf{J}$ Hydrogen Energy 2012; 37: 6912-6921. Epub ahead of print 2012. https://doi.org/10.1016/j.ijhydene.2012.01.018

(16) Salavati-Zadeh A, Esfahanian V, Nourani Najafi SB, et al. Kinetic simulation of flameless burners with methane/hydrogen blended fuel: Effects of molecular diffusion and Schmidt number. Int J Hydrogen Energy 2018; 43: 59725983. Epub ahead of print 15 March 2018. https://doi.org/10.1016/J.IJHYDENE.2017.11.14 9

(17) Cellek MS. Flameless combustion investigation of $\mathrm{CH} 4 / \mathrm{H} 2$ in the laboratory-scaled furnace. Int J Hydrogen Energy 2020; 45: 3520835222. Epub ahead of print 9 December 2020. https://doi.org/10.1016/j.ijhydene.2020.05.233

(18) Cano Ardila FE, Obando Arbeláez JE, Amell Arrieta AA. Emissions and dynamic stability of the flameless combustion regime using hydrogen blends with natural gas. Int $\mathbf{J}$ Hydrogen Energy 2021; 46: 1246-1258. Epub ahead of print 1 January 2021. https://doi.org/10.1016/j.ijhydene.2020.09.236

(19) Shabanian SR, Derudi M, Rahimi M, et al. Experimental and numerical analysis of syngas mild combustion. In: XXXIV Meeting of the 
Italian Section of the Combustion Institute, Italy. 2011.

(20) Huang MM, Shao WW, Xiong Y, et al. Effect of fuel injection velocity on MILD combustion of syngas in axially-staged combustor. Appl Therm Eng 2014; 66: 485-492. Epub ahead of print 2014. https://doi.org/10.1016/j.applthermaleng.2014.02 .033

(21) Huang M, Zhang Z, Shao W, et al. Coalderived syngas MILD combustion in parallel jet forward flow combustor. Appl Therm Eng 2014; 71: 161-168. Epub ahead of print 2014. https://doi.org/10.1016/j.applthermaleng.2014.06 .044

(22) Huang M, Deng H, Liu Y, et al. Effect of fuel type on the MILD combustion of syngas. Fuel 2020; 281: 118509. Epub ahead of print 1 December 2020 . https://doi.org/10.1016/j.fuel.2020.118509

(23) Mardani A, Karimi Motaalegh Mahalegi $\mathrm{H}$. Hydrogen enrichment of methane and syngas for MILD combustion. Int J Hydrogen Energy 2019; 44: 9423-9437. Epub ahead of print 5 April 2019.

https://doi.org/10.1016/J.IJHYDENE.2019.02.07 2

(24) Ebrahimi Fordoei E, Mazaheri K. Effects of preheating temperature and dilution level of oxidizer, fuel composition and strain rate on $\mathrm{NO}$ emission characteristics in the syngas moderate or intense low oxygen dilution (MILD) combustion. Fuel 2021; 285: 119118. Epub ahead of print 1 February 2021. https://doi.org/10.1016/j.fuel.2020.119118

(25) Boussetla S, Mameri A, Hadef A. NO emission from non-premixed MILD combustion of biogas-syngas mixtures in opposed jet configuration. Int $\mathbf{J}$ Hydrogen Energy. Epub ahead of print 5 February 2021. https://doi.org/10.1016/j.ijhydene.2021.01.074

(26) Kim N, Kim Y, Jaafar MNM, et al. Effects of hydrogen addition on structure and NO formation of highly CO-Rich syngas counterflow nonpremixed flames under MILD combustion regime. Int J Hydrogen Energy 2021; 46: 1051810534. Epub ahead of print 8 March 2021. https://doi.org/10.1016/j.ijhydene.2020.12.120

(27) Colorado AF, Herrera BA, Amell AA. Performance of a Flameless combustion furnace using biogas and natural gas. Bioresour Technol 2010; 101: 2443-2449. Epub ahead of print 2010. https://doi.org/10.1016/j.biortech.2009.11.003

(28) Li P, Mi J, Dally BB, et al. Premixed moderate or intense low-oxygen dilution (MILD) combustion from a single jet burner in a laboratory-scale furnace. Energy and Fuels 2011; 25: 2782-2793. Epub ahead of print 2011. https://doi.org/10.1021/ef200208d

(29) Lupant D, Lybaert P. Assessment of the EDC combustion model in MILD conditions with in-furnace experimental data. Appl Therm Eng 2015; 75: 93-102. Epub ahead of print 2015. https://doi.org/10.1016/j.applthermaleng.2014.10 .027

(30) Sánchez M, Cadavid F, Amell A. Experimental evaluation of a $20 \mathrm{~kW}$ oxygen enhanced self-regenerative burner operated in flameless combustion mode. Appl Energy 2013; 111: 240-246. Epub ahead of print 2013. https://doi.org/10.1016/j.apenergy.2013.05.009

(31) Bolhàr-Nordenkampf $\mathrm{M}$, Rauch $\mathrm{R}$, Bosch $\mathrm{K}$, et al. Biomass CHP Plant Güssing - Using Gasification for Power Generation. Proceeding of the 2nd Regional Conference on Energy Technology Towards a Clean Environment 12-14 February 2003, Phuket Thailand 2003; 566-572.

(32) Maxim V, Cormos CC, Cormos AM, et 
al. Mathematical modeling and simulation of gasification processes with carbon capture and storage (ccs) for energy vectors poly-generation. In: Computer Aided Chemical Engineering. Elsevier, pp. 697-702.

(33) Ishii T, Zhang C, Hino Y. Numerical study of the performance of a regenerative furnace. Heat Transf Eng 2002; 23: 23-33. Epub ahead of print 2002. https://doi.org/10.1080/01457630290090473

(34) Zhang C, Ishii T, Hino $\mathrm{Y}$, et al. The Numerical and Experimental Study of NonPremixed Combustion Flames in Regenerative Furnaces. J Heat Transfer 1999; 122: 287-293. Epub ahead of print 1999. https://doi.org/10.1115/1.521466

(35) Aminian J, Galletti C, Shahhosseini S, et al. Numerical investigation of a MILD combustion burner: analysis of mixing field, chemical kinetics and turbulence-chemistry interaction. Flow, Turbul Combust 2012; 88: 597-623.

(36) Galletti C, Parente A, Derudi M, et al. Numerical and experimental analysis of $\mathrm{NO}$ emissions from a lab-scale burner fed with hydrogen-enriched fuels and operating in MILD combustion. Int J Hydrogen Energy 2009; 34: 8339-8351. Epub ahead of print 2009. https://doi.org/10.1016/j.ijhydene.2009.07.095

(37) Inc. Ansys. ANSYS Fluent Theory Guide 19.0. $2018 ; 848$.

(38) Wang L, Liu Z, Chen S, et al. Comparison of different global combustion mechanisms under hot and diluted oxidation conditions. Combust Sci Technol 2012; 184: 259 276. Epub ahead of print 2012. https://doi.org/10.1080/00102202.2011.635612

(39) Roache PJ. Perspective: A Method for Uniform Reporting of Grid Refinement Studies. J
Fluids Eng 1994; 116: 405. Epub ahead of print 1994. https://doi.org/10.1115/1.2910291

(40) Franke J, Hellsten A, Schlünzen H, et al. Best practice guideline for the CFD simulation of flows in the urban environment. COST action 2007; 44: 1-52.

(41) Li P, Wang F, Mi J, et al. MILD combustion under different premixing patterns and characteristics of the reaction regime. Energy and Fuels 2014; 28: 2211-2226. Epub ahead of print 2014. https://doi.org/10.1021/ef402357t

(42) Rafidi N, Blasiak W. Heat transfer characteristics of HiTAC heating furnace using regenerative burners. Appl Therm Eng 2006; 26: 2027-2034. Epub ahead of print 2006. https://doi.org/10.1016/j.applthermaleng.2005.12 .016

(43) Yang W, Blasiak W. Numerical simulation of properties of a LPG flame with high-temperature air. Int J Therm Sci 2005; 44: 973-985. Epub ahead of print 2005. https://doi.org/10.1016/j.ijthermalsci.2005.03.00 
